\title{
RESEARCH IN MILKING INTERVALS APPLYING DIFFERENT TYPES OF MILKING PARLOURS
}

Armins Laurs, Juris Priekulis, Maris Rozentals

Latvia University of Life Sciences and Technologies, Latvia

armins.laurs@promedia.lv, juris.priekulis@1lu.lv, maris009@inbox.lv

\begin{abstract}
The main problem in using the AMS is that cows do not attend the AMS voluntarily. To ensure milking three or four times a day, in many farms cows are driven to the AMS several times a day. Representatives of companies recommend that it only takes place at the beginning and at the end of a workday. In such a case, cows gradually get used to milking as many times a day as it is intended. However, the question is - does this really happen? Next to the concern regarding the provision of the intended milking times a day, farmers are also worried about milking interval dispersion. Appropriate studies were carried out to see what happens in farms, where cows are driven to the AMS in the morning and in the evening only. At the same time, analogous studies were carried out in a holding, where cows were milked with milking parlour. The studies were conducted in two holdings. In the first holding, cows were milked with the AMS, but in the second - with parallel parlour. Ten cows were selected for each experimental group, and the studies lasted for 15 days. They determined the number of milking times per day (milking/day), and the distribution and dispersion of milking intervals. The results of the study showed that in practice it was possible to achieve that the AMS is attended more than 3 times a day, on the condition that only cows with a milking interval of more than 13 hours are driven to the milking site in the morning and in the evening. However, at the same time it was found that there would always be cows in a herd that have been milked both more and less than three times a day. When milking with the AMS, milking intervals vary widely, yet in $80 \%$ of the cases they vary between 5 and 6 hours. First lactation cows (as compared to older cows) are more inert to attend the AMS, and their dispersion of milking intervals is greater. In turn, milking parlour ensures that all cows undergo the set number of milking times and it helps keep smaller fluctuations in milking intervals. If 60 to 80 cows are milked in one group, the fluctuation of the milking interval does not exceed 2 hours.
\end{abstract}

Keywords: milking, AMS, parlours, intervals.

\section{Introduction}

Today, the automatic milking systems (AMS) are widely used both in Latvia and in other EU countries. In the survey involving owners of dairy farms in Latvia, who use the AMS, the reluctance of cows to attend the AMS voluntarily was underlined as a key problem for the use of the AMS. In order to ensure milking of high-yielding cows three or four times a day, as recommended by best dairy farming practices, it is very often necessary to drive cows to the AMS several times a day, and it increases the workload of livestock keepers. In turn, representatives of AMS manufacturing companies claim that it is enough to drive the "lazy" cows to the milking site only at the beginning and at the end of a workday. If the cows are not bothered at other times, they will get accustomed to such an order and will attend the AMS on a regular basis. However, given the results of the farm owner survey, the question is: is it really so?

Moreover, in practice, it has long been proved that, when milking high-yielding cows three or even four times a day with traditional milking equipment keeping constant milking intervals, the milk yields are increasing. Therefore, owners of farms using the AMS are concerned not only about the ability of providing the expected number of milking times per day, but also about the unevenness of milking intervals.

Reviewing the scientific literature [1-7], we did not find any studies on the above issue, and therefore it was decided to conduct such research. This research was also carried out in a farm that used milking parlour, since changes in milking intervals are also possible with this milking technology.

The following tasks were set for the study:

- To establish distribution and dispersion of the number of milking times (milking/day) and milking intervals in the farm, where cows that are not milked at the set time are driven to the AMS in the morning and in the evening only;

- To establish the distribution of milking intervals in the farm, where cows are milked with milking parlour; 
- To compare the results of the research in both farms.

\section{Materials and methods}

The research was carried out in two agricultural holdings. In the first holding, cows were milked with the AMS, and in the other - with parallel parlour. Table 1 shows the main characteristics of the holdings.

Table 1

Characteristics of the farms included in the studies

\begin{tabular}{|c|c|c|}
\hline Parameter & Holding 1 & Holding 2 \\
\hline Number of milking cows & 130 & 246 \\
\hline Average annual productivity & 9480 & 11500 \\
\hline Type of milking equipment & $\begin{array}{l}\text { AMS (DeLaval - VMS with } \\
\text { free cow traffic) }\end{array}$ & $\begin{array}{l}\text { Parallel parlour (DeLaval - } \\
2 \times 10)\end{array}$ \\
\hline Number of milking equipment & 2 & 1 \\
\hline Number of servicing staff & 1 (2 hours/day) & $\begin{array}{c}1 \text { milker and } 1 \text { cattle breeder } \\
\text { (both } 16 \text { hours/day) }\end{array}$ \\
\hline $\begin{array}{l}\text { Cow group structure and } \\
\text { number of cows per group }\end{array}$ & 2 groups, 63 cows in each & $\begin{array}{c}\text { Group 1: first lactation }-60 \\
\text { cows } \\
\text { Group 2: high-yielding cows - } \\
\quad 85 \text { cows } \\
\text { Group 3: high-yielding cows } \\
\text { with a long milking time - } \\
\quad 63 \text { cows } \\
\text { Group 4: other cows }-38 \text { cows }\end{array}$ \\
\hline Milking permission setting & $\begin{array}{l}\text { For cows in the } 1 \text { st phase of } \\
\text { lactation }-5 \mathrm{~h} \\
\text { For cows in the } 2 \text { nd phase of } \\
\text { lactation }-6 \mathrm{~h}\end{array}$ & 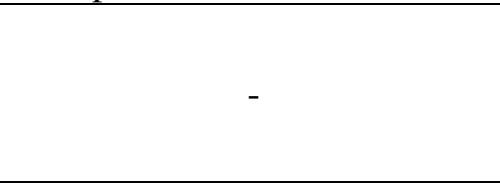 \\
\hline $\begin{array}{l}\text { Schedule for driving cows to } \\
\text { the milking site with the AMS }\end{array}$ & $\begin{array}{c}2 \times \text { a day (7:00-10:00 and } \\
\text { 16:00-19:00) only the cows } \\
\text { that have not been milked } \\
\text { for }>13 \text { hours) }\end{array}$ & - \\
\hline $\begin{array}{l}\text { Number of milking times a } \\
\text { day using parallel parlour }\end{array}$ & (n) & $\begin{array}{c}\text { Groups } 1,2 \text { and } 3: 3 \times \text { a day } \\
\text { Group 4: } 2 \times \text { a day }\end{array}$ \\
\hline $\begin{array}{l}\text { Start of milking time using } \\
\text { parallel parlour }\end{array}$ & - & $\begin{array}{c}\text { In the morning - } 6: 00 \text {, during } \\
\text { the day }-13: 30 \text {, in the evening } \\
-20: 00\end{array}$ \\
\hline
\end{tabular}

Three groups of cows were selected for the study according to the plan shown in Table 2.

Selection principles for cow groups included in the study

\begin{tabular}{|c|c|c|c|c|c|c|c|}
\hline \multirow{2}{*}{$\begin{array}{c}\text { Type of } \\
\text { milking } \\
\text { equipment }\end{array}$} & $\begin{array}{c}\text { Designation } \\
\text { of the cow } \\
\text { group }\end{array}$ & $\begin{array}{c}\text { Lactation } \\
\text { number }\end{array}$ & $\begin{array}{c}\text { Number } \\
\text { of cows } \\
\text { in the } \\
\text { group }\end{array}$ & $\begin{array}{c}\text { Average } \\
\text { milk yield } \\
\text { per group } \\
\text { of cows, } \\
\text { kg.day }\end{array}$ & $\begin{array}{c}\text { Number of } \\
\text { cows with } \\
\text { milking } \\
\text { permission } \\
\text { setting }\end{array}$ & $\begin{array}{c}\text { Number } \\
\text { of } \\
\text { milking } \\
\text { times per } \\
\text { day }\end{array}$ \\
\hline AMS & A & First lactation & 10 & 24 & 10 & - & - \\
\hline AMS & B & $\begin{array}{c}\text { 2nd and 3rd } \\
\text { lactation }\end{array}$ & 10 & 42 & 4 & 6 & - \\
\hline $\begin{array}{c}\text { Parallel } \\
\text { parlour }\end{array}$ & $\mathrm{C}$ & $\begin{array}{c}\text { First-calvers } \\
\text { 2nd and 3rd } \\
\text { lactation }\end{array}$ & 10 & 48 & - & - & $3 \times$ \\
\hline
\end{tabular}


Information on the cow milking was obtained from the AMS management system and from the parallel parlour management system. The studies were based on the data collected for 15 days.

\section{Results and discussion}

Table 3 shows the average number of milking times per day using the AMS (for Groups A and B) obtained in the studies.

Average number of milking times per day, using the AMS

Table 3

\begin{tabular}{|c|c|c|c|c|c|c|c|c|c|c|c|}
\hline \multirow{3}{*}{ Cow group } & \multicolumn{11}{|c|}{ Average number of milking times per day } \\
\hline & \multicolumn{10}{|c|}{ Individually for each cow } & \multirow{2}{*}{$\begin{array}{c}\text { On average } \\
\text { for the cow } \\
\text { group }\end{array}$} \\
\hline & 1. & 2. & 3. & 4. & 5. & 6. & 7. & 8. & 9. & 10. & \\
\hline $\begin{array}{c}\text { First lactation } \\
\text { (Group A) }\end{array}$ & 3.5 & 3.6 & 4.1 & 2.7 & 1.9 & 2.6 & 2.9 & 3.1 & 3.3 & 3.0 & 3.1 \\
\hline $\begin{array}{l}\text { 2nd and 3rd } \\
\text { lactation } \\
\text { (Group B) }\end{array}$ & 3.7 & 3.5 & 2.7 & 3.3 & 3.8 & 3.8 & 3.0 & 3.0 & 2.9 & 3.4 & 3.3 \\
\hline
\end{tabular}

The table shows that Group A cows milked on average 3.1 times a day, and Group B cows 3.3 times a day, although the milking permission setting allows 4.0 and 4.8 milking times respectively. Moreover, many cows have milked less than three times. In the group of first-calvers, this was observed in $40 \%$, but in the 2nd and 3rd lactation group - in $20 \%$ of the cases. Moreover, in the group of first-calvers there was even a cow that milked on average only 1.9 times a day. There is also a great dispersion in the number of milking times. In the group of first-calvers it ranges from 1.9 to 4.1 times a day, while in the 2 nd and 3rd lactation group it is 2.7 and 3.8 times, respectively.

Figure 1 shows the distribution of milking intervals in the group of first-calvers (A) found in the studies.

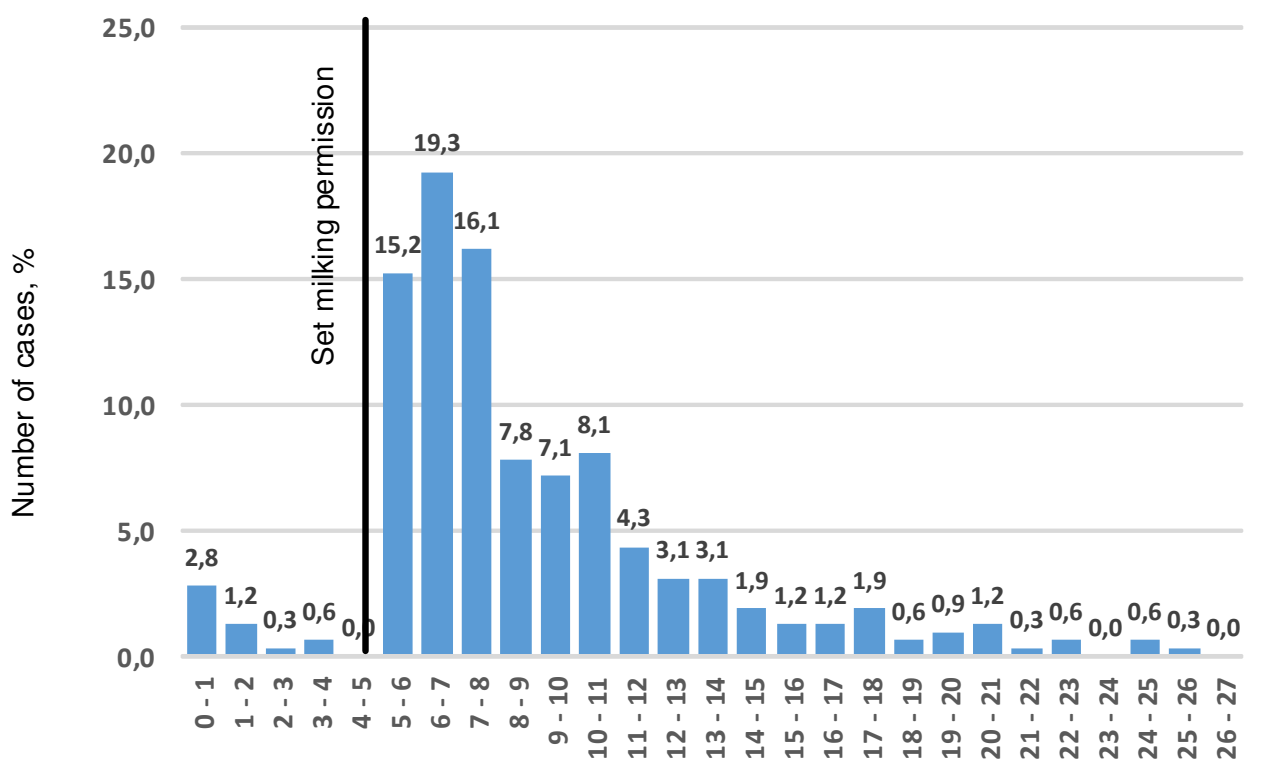

Average milking interval, $\mathrm{h}$

Fig. 1. Distribution of milking intervals in group of first - calvers (A)

The figure shows that in $4.9 \%$ of all milking times, cows have milked before the set milking permission time. Judging by the fact that the early milking permission times are relatively small, this permission was given, because the previous milking had been inadequate. Cows with a milking interval of more than 13 hours (i.e., the milking permission time exceeds 8 hours) have milked less than three times a day. Such cases account for $13.8 \%$. 
Figure 2 shows the distribution of milking intervals among the 2nd and 3rd lactation cows (Group B).

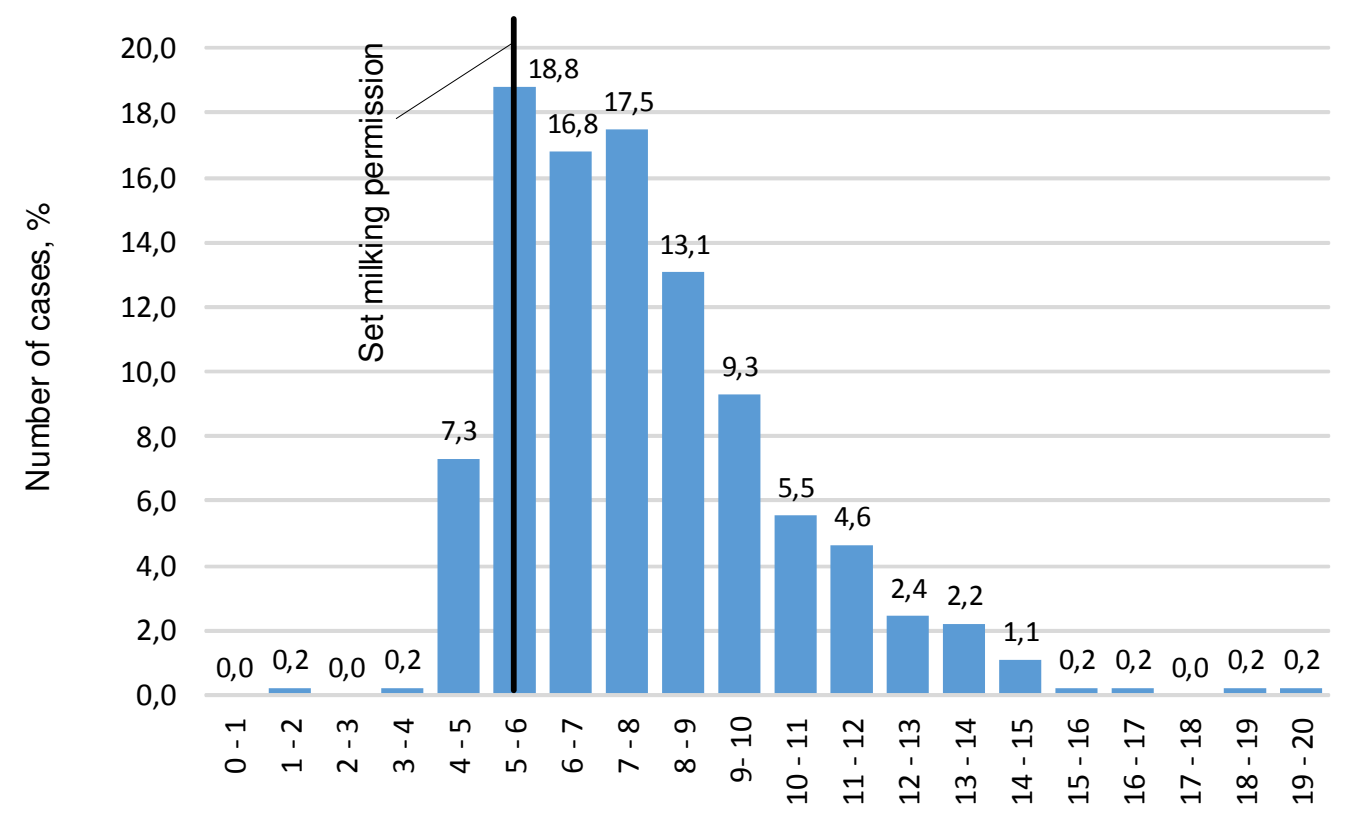

Average milking interval, $\mathrm{h}$

Fig. 2. Distribution of milking intervals in group of $2 \mathrm{nd}$ and 3rd lactation cows (B)

The figure shows that in $7.9 \%$ of the cases cows have milked before the set milking time. It can be estimated that in this case the early permission was received shortly before the set permission, which indicates that it was provided by the AMS milk secretion forecasting system. The figure also shows that in $3.7 \%$ of the cases cows have milked fewer than 3 times a day.

Figure 3 shows the distribution of milking intervals for Group C cows. This group of cows consists of first-calvers, as well as of 2nd and 3rd lactation cows, and they are milked 3 times a day using a stand-type milking equipment with parallel positioning of cows.

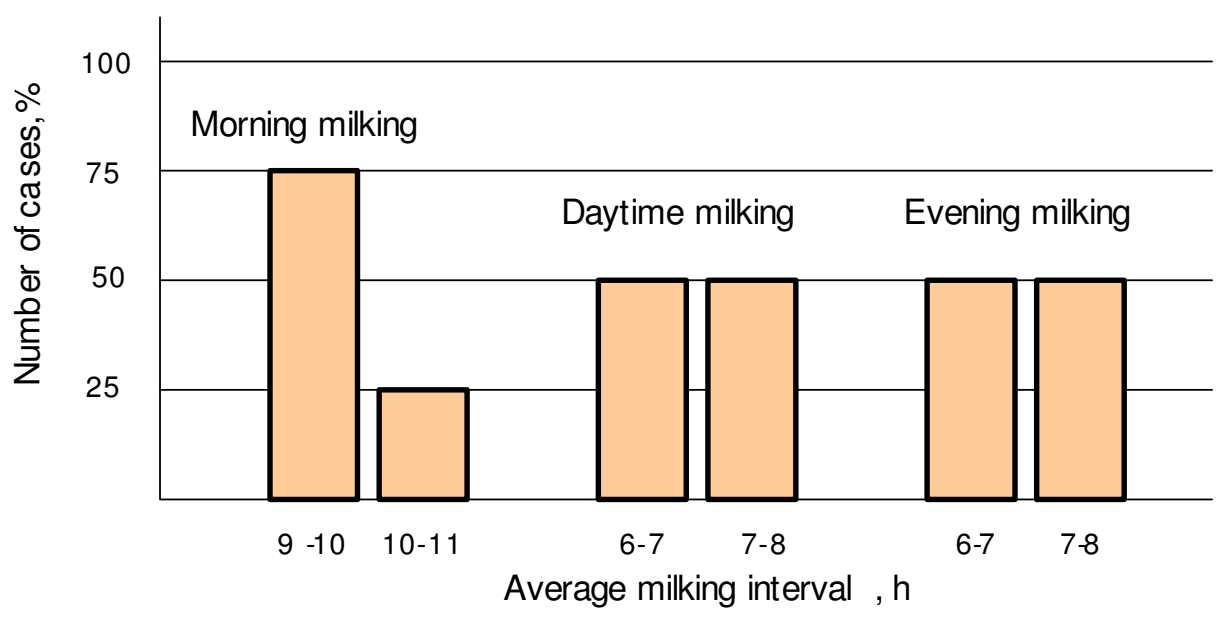

Fig. 3. Distribution of milking intervals for cow group (C) milked with parallel parlour

The figure shows that milking parlour ensures that all cows are milked as many times a day as it is planned. In this case, all cows are divided into groups. At a certain time, each group of cows is driven to the pre-milking area, but they can enter the milking parlour any time they wish. When all the cows in the respective group have been milked, the next group of cows is driven to the pre-milking area. Thus, the milking interval can vary within the milking time range of one cow group, and in this case, it is 2 hours. 
So far, in practice it has been proved that milking twice a day is sufficient, and productivity potential of cows is fully used, if the milk yield does not exceed $5000 \mathrm{~kg}$ per year. Nevertheless, today it is not uncommon for cows to be more productive; therefore, this milking frequency may be insufficient. Studies have shown that, when milking high-yielding cows three times a day (compared to milking twice a day), the milk yield increases by $10-15 \%$, but after switching to four milking times a day - by up to $22 \%$ [8-10]. Moreover, it has been found that a further increase in the milking frequency is not desirable, as it is not possible to produce full milk ejection reflex at very short intervals (shorter than 4-5 hours), resulting in disturbances in the milk output process [11].

Thus, it can be concluded that cows with a low milk yield can be milked twice a day, but highyielding cows should be milked 3 or 4 times a day.

Moreover, a number of studies [11] have confirmed that milk secretion and milk accumulation in the udder are closely related processes. Continuous milk secretion requires regular emptying of the udder, since once a certain level of milk accumulation in the udder is reached, milk secretion intensity drops significantly. This is taken into account in practice, when setting the milking regime. As noted earlier, in order to make full use of productivity potential of high-yielding cows, they should be milked three or four times a day. However, only on the condition that the intervals between milking times are more or less equal.

Unfortunately, using the traditional milking technologies, milking 3 or 4 times a day is problematic, since it would further exacerbate the problem of the increasing labour costs, as well as fuel milker dissatisfaction with the difficult working conditions and inconvenient working hours.

All these problems were addressed by developing and implementing the AMS in practice. Nevertheless, if the problem of workload was thus resolved easily, it is more difficult to achieve that cows attend the milking site voluntarily and at the desired frequency. Moreover, the assumption that the fodder that cows can receive from the AMS and their desire to be milked, when milk has accumulated in the udder, are strong enough factors for cows to attend the AMS according to the intended programme, has not been confirmed.

Currently, in practice the desired milking frequency is programmed for each cow individually, depending on the lactation phase and daily milk yield. As the lactation phase and milk yield change, also the milking frequency setting changes. This is done by setting the minimum accepted milking interval (milking permission), i.e. cows can enter the AMS during this time, but milking does not take place. To milk cows that are significantly delayed in attending the AMS, they must be driven to the milking site. As mentioned in the introduction to the article, companies recommend that the "lazy" cows be driven to the milking site twice a day (in the morning and in the evening), and, what is more, only those cows that have not been milked for more than 13 hours should be driven. Besides, there is an opinion [3] that cow movement to the AMS should be considered as normal, if the herd is milked on average 2.4-2.8 times a day.

In the holding selected for our study, cows already for a long time are milked according to the AMS manufacturer's recommendations. However, the results of the study show that when milking cows with the AMS, the milking times are delayed and milking intervals tend to differ. It means that this daily milking regime with the AMS is not even close to the desirable. The question then arises: does milking with the AMS at milking intervals of 8 and 6 hours (corresponding to 3 and 4 milking times per day) can produce the same milk yields as milking 3 and 4 times a day with traditional milking equipment? This could be the objective for future research.

\section{Conclusions}

1. In practice, it can be achieved that cows attend the AMS on average more than 3 times a day. Yet, in such cases it must be ensured that cows, which have not attended the AMS for more than 13 hours, are driven to the milking site twice a day (in the morning and in the evening). However, in any herd there will always be cows that will have milked independently more than 3 times a day.

2. If the cows that have not been milked are driven to the AMS only in the morning and in the evening, the milking intervals vary widely; however, in $80 \%$ of the cases, using the set milking permission time as the point of reference, they vary between 5 and 6 hours. 
3. First lactation cows (as compared to older cows) are more reluctant to attend the AMS and they have greater milking interval dispersion.

4. The use of milking parlour ensured that all cows were guaranteed to have the set number of milking times a day. Moreover, the fluctuations in the milking intervals, when milking groups of 60 to 80 cows, are shorter than 2 hours.

5. In light of the results of this study, it is doubtful that the introduction of the AMS per se increases the productivity of cows, since the set number of milking times is not always ensured for all cows; also, the milking intervals tend to vary in very wide ranges. Most likely, such a situation does not fully use the potential of cow productivity that can be achieved through regular milking of cows 3 or 4 times a day at more or less regular milking intervals.

\section{Acknowledgements}

We would like to express our deepest gratitude to Baiba Velika, DeLaval Head Management Specialist in the Baltic States, for her devoted help and advice in obtaining raw data from milking equipment management systems.

\section{References}

[1] Harms J. H Untresuchungen zum Einsatz verschiedener Varianten des Tierumtriebs bei automatischen Melksystemen (Einboxanlage). (Investigations on the use of different variants of animal movement in automatic milking systems (Einboxanlage)) Dissertation. Weihenstephan: Technischen Universität München, 2005. pp. 79-100. (In German)

[2] Artman R. Ergebnisse aus langjährigem Praxiseinsatz von Melkrobotern. (Results from years of practical use of milking robots). Beiträge der 7. Internationale Tagung „Bau, Technik und Umwelt in der landwirtschaftlichen Nutztierhaltung 2005”. KTBL: Darmstadt, 2005, pp. 145-150. (In German)

[3] Hulsen J. Melken mit dem Roboter. (Milking with the robot). Zutphen: Roodbont, 2008, 52 p. (In German)

[4] Schön H. u.a. Automatische Melksysteme. (Automatic milking systems). KTBL: Darmstadt, 2000, pp. 94-96. (In German)

[5] Wall E. H., MeFadden T. B. Use. Enhancing milk producion effeciecy by frequent milking of dairy cows. Journal of Animal Science 86 (suppl 1), 2008, pp. 27-36

[6] Fuchs C., Fübecker A., Harm J. u. a. Automatische Melksysteme. (Automatic milking systems). KTBL: Darmstadt, 2013, pp. 107-108. (In German)

[7] Bonsels T. Melkroboter Menagement. (Milk Robot Menagement). Landwirtschaftsverlag: Münster-Hiltrup, 2012, pp. 68-69. (In German)

[8] Meinhold K.\& Rosegger S. Die Bedeutung der Melk- und Fütterungsfrequenz für die Wirtschaftlichkeit der Milcherzeugung. (The importance of milking and feeding frequency for the economic efficiency of milk production). Tierzüchter 10, 1977. pp. 44-45. (In German)

[9] Phillipps, D. S.M., Woolford, M. W., Copeman. P. J. A..The Implications of Milking Menagement Strategies Involving Variations of Milking Frequency in the Immediate Post-partum Period. Proceedings of the New Zealand Society of Animal Production 40, Hamilton: New Zealand, 1980. pp. 166-174.

[10] Poole, D. A. The Effects of Milking cows three Times Daily. Animal Production 2, 1982. pp. 197-121.

[11] Hamann J., Dodd F.H. Milking Routines. In: Bramley A.J. (ed.) Machine Milking and Lactation. Insight Books: Berkshire - Vermont, 1992. pp. 69-96. 